\title{
Theoretical Contents of the Subject: "Childhood, Health and Nutrition
}

\author{
Cecilia Martinez Costa* \\ Department of Pediatrics, Obstetrics, and Gynecology, University of Valencia, Spain \\ Submission: October 17, 2016; Published: October 27, 2016 \\ *Corresponding author: Cecilia Martinez Costa, Department of Pediatrics, Obstetrics, and Gynecology, University of Valencia, Spain
}

\section{Introduction}

Institutionalized education at school age is probably one of the most effective strategies to prevent a wide range of chronic diseases. During the last five years our University has incorporated a subject called "Childhood, Health and Nutrition" into is official Education program. The aim of this matter is to promote disease prevention in children, there by improving their current health status and safe guarding their future adult life [1-5].

\section{Objectives}

1. To offer basic knowledge about the biology, psychology and sociology of child health at different pediatricages: infant, pre-scholar, scholar and adolescent.

2. To provide future teachers and educators with the knowledge and practical skills to encourage healthylifestyle habits and positive attitudes in children, with a special emphasis on the importance of nutrition and physical exercise in order to prevent chronic diseases in childhood and adult life.

3. To instruct future teachers and educators in first-aid management of pediatric emergencies.

4. To implicate teachers and educators to contribute in the management of the main childhood diseases at school.

\section{Overview}

This matter constitutes a core subject of the first academic year of the Degree in Educational Studies at the University of Valencia. Teaching is delivered by a combination of lectures, seminars, workshops, and tutorials. The subject's syllabus (4.5 ECTS credits) is distributed as follows: -45 teachingh ours including theoretical and practical lessons (20 units of 2 hours 1.5/0.5, respectively), and tutorials for team work preparation. -67 non-presential hours for team work and individual studying.

-Other additional educational sources include workshops as complementary activities and updated information available on a community virtual platform (http://aulavirtual.uv.es/).

\section{Theoretical Contents}

The topics covered by this subject include the following: -Lessons 1 and 2 describe the biological characteristics of childhood. They include the criteria to define pediatricages and to describe the main features of somatic growth and development. The second part explains the major milestones of sensory and psychomotor development of children and the approach to the early detection at school of sensory disturbances and behavioral patterns at school. -Lessons 3 to 6 explain the role of nutrition in childhood, comparing it to that in adulthood. They specify the components of energy expenditure and daily caloric

requirements, provide the skills for establishment of healthy dietary 2 recommendations at different ages, and explain relevant aspects for the elaboration of a school menu, establishment of adequate environmental conditions, hygiene, composition, food security etc.

Specific calculations are performed. -Lessons 7 and 8 explain the benefits of sport in child health, the mechanisms of adaptation to exercise, and the nutritional needs and nutritional recommendations. -Lesson 9 covers the main toxic habits (alcohol, tobacco and other drugs) during school and adolescence, together with the clinical and social consequences and prevention strategies at school. -Lessons 10 and 11 are dedicated to the main pediatric infections. The principal clinical manifestations, signs of severity and activity in schools, and hygienic and immunological prevention strategies for infectious diseases are reviewed. -Lessons 12 to 15 cover the most common childhood diseases divided according to the following groups:

a. Accidents: Signs of serious illness and first-aid management at school. Security tasks;

b. Poison, bites and stings: Signs of serious illness and first aid management at school;

c. Diabetes; Asthma and other lung diseases; Celiac disease; Heart disease; Intestinal parasites; Epilepsy. 
Hematological and oncological diseases; Metabolic diseases. -Lessons 16 to 18 include the nutritional disorders in childhood:

a. Obesity and comorbidities (hypertension, hypercholesterolemia, and liver disorders, orthopaedic and psychological;

b. Eating disorders;

c. Malnutrition and specific nutritional deficiencies. Particular attention is given to the prevention of these diseases, together with the prevention of tooth decay and other disorders such as osteoporosis.

-Lesson 19 focuses on cerebralpalsy, that is, the main encephalopathy in childhood, and its related nutritional risk. -Finally, lesson 20 is exclusively practical classroom about basic cardiopulmonary resuscitation guidelines.

\section{Limitations}

The teaching of this subject faces several difficulties. In particular, the fact that this subject is taught during the first academic year, when students' educational level is still rather limited, restrains students from thoroughly understanding the crucial importance of improving health during childhood and the eventual consequences in adulthood

\section{References}

1. http://www.eaie.org/

2. European Commission (2012) The EuropeanHigher Education Area in 2012: Bologne Process. Implementation report. EACEA P9 Eurydice, Brussels, Belgium.

3. https://www.msssi.gob.es/

4. http://www.magna-charta.org/resources/files/text-of-the-bolognadeclaration

5. http://www.uv.es/uvweb/universidad/es/estudios-grado/grau1285846094474/Titulacio.html?id=1285847460706

\begin{tabular}{|l|}
\hline \multicolumn{1}{|c|}{ Your next submission with JuniperPublishers } \\
will reach you the below assets \\
- Quality Editorial service \\
- Swift Peer Review \\
- Reprints availability \\
- E-prints Service \\
- Manuscript Podcast for convenient understanding \\
- Global attainment for your research \\
- Manuscript accessibility in different formats \\
( Pdf, E-pub, Full Text, Audio) \\
- Unceasing customer service \\
Track the below URL for one-step submission \\
http://juniperpublishers.com/online-submission.php \\
\hline
\end{tabular}

